уДК 94(517): 94(4)"375/1492"(093)

DOI: $10.22378 / 2313-6197.2017-5-2.276-289$

\title{
THE CHRISTIAN NOBLES AT THE COURT OF GREAT KHAN, AS DESCRIBED IN MEDIAEVAL EUROPEAN SOURCES ${ }^{1}$
}

\author{
Vladimír Liščák \\ Oriental Institute, Czech Academy of Sciences \\ Prague, Czech Republic \\ vliscak@gmail.com
}

Research objectives: "Moreover, the chief princes of his whole empire, more than thirty thousand in number, who are called Alans, and govern the whole Orient, are Christians either in fact or in name, calling themselves the Pope's slaves, and ready to die for the Franks." With these words John of Marignola, a notable traveller to the Far East in the fourteenth century and a legate to the Great Khan of Cathay, attested in his Cronica Boemorum the presence of certain Christian nobles of the Alan race in the service of the Mongol-Chinese emperor. The immediate impetus for Marignola's mission was that in 1336 the Great Khan Ukhaghatu Toghon-Temür sent a delegation of sixteen "Franks" (Franquis), as the Mongols called Europeans, ad Papam, Dominum Christianorum in Franchiam. They brought two letters to the pope: one purporting to be from the Great Khan himself, and the other from certain princes of the Christian Alans in his service. By the coming of the Mongolian legation in Avignon in 1338, we are informed, among others, that the successor of John of Montecorvino, the first archbishop in Khanbalik, had never reached his destination, as well as the other succeeding archbishops to Khanbalik.

Research materials: Marignola's mission was important not only with its spiritual message, but rather with an excellent choice of gift for the Great Khan. Western messengers brought with them, among the gifts from the Pope in Rome, a singularly auspicious present: a magnificent black horse with white hind hooves. Marignola, in his Cronica Boemorum, identifies the Christian dignitaries at the court of the Great Khan as the Alans. We know of them from earlier sources, but mostly under the generic name "Christians" or "Nestorian Christians". John of Montecorvino reportedly converted many Alans (he did not mention their name) to Roman Catholic Christianity in addition to Armenians in China. According to the Annals of the Yuan Dynasty, in 1229 and 1241, when army of Ögedei Khan reached the Country of the Aas (Alans), their chief submitted at once and a body of one thousand Alans was kept for the private guard of the Great Khan. Möngke Khan enlisted in his bodyguard half of the troops of Arslan, an Alan prince, whose younger son Nicholas took a part in the expedition of the Mongols against Qarajang (Yunnan). Marco Polo mentions Alania among the countries conquered by the Mongols, and devotes a whole chapter to an account of the slaughter of certain Alans who were Christians and formed a corps in Kublai's army. The number and influence of Christians in China at the end of the thirteenth century may be gathered from the letter of John of Montecorvino, and in the first part of the following century from the report of the Archbishop of Soltania, who describes them as more than thirty thousand in number, and passing rich people. That Christians continued to rise in influence during the short remainder of the Mongol reign appears probable from the position which we find the Christian Alans to occupy in the empire at the time of the visit of John of Marignola. Also Odoric of Pordenone several times mentioned "great barons" (magni barones aspicientes solum ad personam regis) at the court of the Great Khan. Interesting is Odoric's pleasant

\footnotetext{
1 This article was kindly supported by MOFA Taiwan Fellowship (外交部「臺灣獎助金」) 2016.
} 
anecdote concerning his presentation of apples to Yesün Temür Khan which reveals the easy acceptance of the Latin Christians by the emperor and his top generals - the hereditary Alan guards that protected Kublai's descendants.

Results and novelty of the research: What happened to the multitude of converts that John of Montecorvino and others claimed for Rome, when the Ming dynasty took control in 1368? A recent study suggests that Christian worship, instead of dying out under this pressure, simply became more circumspect in its visible forms of worship. Some fifteenthcentury Christians migrated from the coast or other cities to smaller communities, in order to worship quietly as they wished.

Keywords: religion in mediaeval China, Yuan Dynasty China, Christianity in the Great Khan court, Franciscan missions, Christian Alan nobility, Western mediaeval sources

For citation: Liščák V. The Christian Nobles at the Court of Great Khan, as Described in Mediaeval European Sources. Zolotoordynskoe obozrenie=Golden Horde Review. 2017. Vol. 5, no. 2, pp. 276-289. DOI: 10.22378/2313-6197.2017-5-2.276-289

Recessimus de Auinione mense Decembris, pervenimus Neapolim in principio quadragesime et ibi usque ad pascha, quod fuit in fine Marcii expectavimus navigium Januensium, venturum cum nuncciis Thartarorum, quos misit Kaam de Cambalec, maxima civitate, ad papam pro mittendis legatis et ad aperiendam viam et fedus componendum cum christianis eo, quod multum honorat et diligit fidem nostram. Summi eciam principes sui imperii tocius plus quam triginta millia, qui vocantur Alani et totum gubernant imperium orientis, sunt christiani re vel nomine et dicunt se sclavos pape, parati mori pro Franquis; sic enim vocant nos, non a Francia, sed a Franquia. Horum primus apostolus fuit frater Johannes dictus de Monte Coruino, qui primo miles, judex et doctor Friderici imperatoris post lxxii annos factus frater Minor doctissimus et scientissimus [7, p. 494-495]2.

With these words John of Marignola (Iohannes a Sancto Laurentio, Iohannes de Florentia, Giovanni de' Marignolli, b. before 1290, fl. 1338-1353), a notable traveller to the Far East in the fourteenth century and a legate to the Great Khan of Cathay, attested in his Cronica Boemorum the presence of certain Christian nobles of the Alan race in the service of the Mongol-Chinese emperor. In other part of his text also mentions:

\footnotetext{
2 "We set out from Avignon in the month of December, came to Naples in the beginning of Lent, and stopped there till Easter (which fell at the end of March), waiting for a ship of Genoa, which was coming with the Tartar envoys whom the Kaan had sent from his great city of Cambalec to the Pope, to request the latter to despatch an embassy to his court, whereby communication might be established, and a treaty of alliance struck between him and the Christians; for he greatly loves and honours our faith. Moreover, the chief princes of his whole empire, more than thirty thousand in number, who are called Alans, and govern the whole Orient, are Christians either in fact or in name, calling themselves the Pope's slaves, and ready to die for the Franks. For so they term us, not indeed from France, but from Frank-land. Their first apostle was Friar John, called De Monte Corvino, who seventy-two years previously, after having been soldier, judge, and doctor in the service of the Emperor Frederic, had become a Minor Friar, and a most wise and learned one." - Transl. by Henry Yule in [30, p. 210]. - Cf. also Národní knihovna České republiky [National Library of the Czech Republic], sign. I.D.10 (Chronica de rebus bohemicis gestis, $15^{\text {th }}$ century), f. 3v (facsimile of the only known ms. online: $<$ http://v2.manuscriptorium.com/apps/main/index.php?request=show_tei_digidoc\&docId=set04 042630\&client $=>$ ).
} 
“...et est hodie maior et nobilior nacio mundi et homines pulcriores et forciores; quorum auxilio Tartari optinuerunt imperium orientis et sine quibus nunquam habuerunt victoriam gloriosam. Conduxit enim Cingwis Caam, primus Thartarorum rex, de eis LXXII principes, quando voluit precepto dei castigare mundum" [7, p. 507] $]^{3}$.

John of Marignola was the last of the major Franciscans send out to the court of Mongolian khans and emperors in Yuan China. He came from a Florentine patrician family, received a good education, and lectured (from about 1330 to 1338 ) at the University of Bologna, famous for the study of canon law. In December 1338 he was sent by Benedict XII. (pope 1335-1342) from Avignon, then seat of the Holy Father, to the Mongolian court.

The immediate impetus for Marignola's mission was that in 1336 the Great

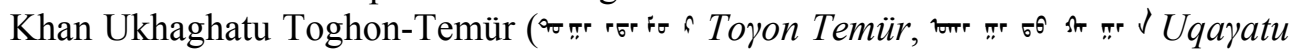

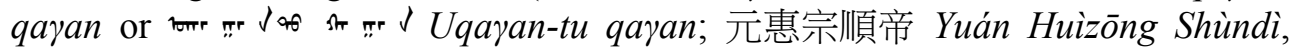
ruled 1333 to 1368/1370) sent a delegation of sixteen "Franks" (Franquis), as the Mongols called Europeans, ad Papam, Dominum Christianorum in Franchiam. The delegation was led by a Genoese, Andrea di Nascio, accompanied by another Genoese, Andalò di Savignone, and fourteen other persons. They brought two letters to the pope: one purporting to be from the Great Khan himself, and the other from certain princes of the Christian Alans in his service [26, p. 179; 14, p. 314] ${ }^{4}$.

The letter of the Great Khan was as follows:

"In fortitudine Omnipotentis Dei, Imperatoris Imperatorum prceceptum.

Nos mittimus Nuncium nostrum Andrceam Francum cum quindecim sociis ad Papam, Dominum Christianorum in Franchiam ultra septem maria, ubi sol occidit, ad aperiendum viam nunciis scepe mittendis per nos ad Papam, \& per Papam ad nos, \& ad rogandum ipsum Papam, ut mittat nobis suam benedictionem, \& in orationibus suis Sanctis semper memoriam faciat de nobis. Et quod Alanos servitores nostros, filios suos Christianos, habeat recommendatos. Item quod adducant nobis ab occasu solis equos, \& alia mirabilia. Scripta in Cambalec in anno Rati mense sexto, tertia die lunationis [= 11 July 1336]" [23, p. 209]5.

3 "They form at this day the greatest and noblest nation in the world, the fairest and bravest of men. It is by their aid that the Tartars have won the empire of the east, and without them they have never gained a single important victory. For Chinghiz Caam, the first king of the Tartars, had seventy-two of their princes serving under him when he went forth under God's providence to scourge the world." - Transl. by Henry Yule in [30, p. 248]. - Cf. also Národní knihovna České republiky [National Library of the Czech Republic], sign. I.D.10 (Chronica de rebus bohemicis gestis, $15^{\text {th }}$ century), f. $14 \mathrm{v}$ (facsimile of the only known ms. online: $<$ http://v2.manuscriptorium.com/apps/main/index.php?request=show_tei_digidoc\&docId=set04 042630\&client=>).

4 “[Tartarorum Imperator Legatos mittit ad Pontificem.] Ineunte hoc anno pervenerunt Avenionem Legati Imperatoris maximi Tartarorum [ ... ] Ita etiam ipsi testati sunt, procipue Principes Alanorum, scriptis per eosdem Legatos litteris, quibus Imperatoriam erga se depredicant beneficentiam, et gratias a Pontifice rependi desposcunt ..." [23, p. 209]. Cf. [11, p. 249-252].

5 "In the strength of the Omnipotent God! The Emperor of Emperors commandeth: We send our envoy, Andrew the Frank, with fifteen others, to the Pope, the Lord of the Christians, in Frank land beyond the Seven Seas where the sun goes down, to open a way for the frequent exchange of messengers between us and the Pope; and to request the Pope himself to send us his blessing, and always to remember us in his holy prayers; and to commend to him the Alans, our servants and his Christian sons. Also we desire that our messengers bring back to us horses and 
In the letter of Alans, the Pope was asked to send a new archbishop after the death of John of Montecorvino (Giovanni da Montecorvino, 1247-1328), archbishop of Khanbalik (r r or ir Q Qanbaliq, 汗八里 Hànbālì , 元大都 Yuán Dàdū), the capital of the Yuan Dynasty, in 1307-1328, who "has died eight years before" (qui tamen mortuus est ante octo annos, in quibus fuimus sine gubernatore, \& sine spirituali consolatione):

"[Epistola Alanorum ad Papam] In fortitudine omnipotentis Dei, \& in honore Imperatoris Domini nostri.

Nos Futim Juens, Caticen Tungii, Gemboga Evenzi, Joannes Juckoy, sanctum Patrem Dominum Papam nostrum, capitibus ad terram positis, pedes osculantes, salutamus, petentes benedictionem suam \& gratiam, \& quod in orationibus suis Sanctis faciat de nobis memoriam, \& numquam obliviscatur nostri. Hoc autem sanctitati vestrce sit notum, quod longo tempore fuimus informati in fide Catholica, \& salubriter gubernati, \& consolati plurimum per Legatum vestrum fratrem Joannem, valentem, sanctum, \& sufficientem virum, qui tamen mortuus est ante octo annos, in quibus fuimus sine gubernatore, \& sine spirituali consolatione, licet audierimus, quod providistis de alio legato, ille tamen nondum venit. Quare supplicamus Sanctitati Vestrce, quod mittatis nobis bonum, sufficientem, ac sapientem Legatum, qui curam habeat de animabus nostris, \& quod cito veniat, quia male stamus sine capite, sine informatione, \& sine consolatione, supplicamus etiam sapientice vestrce, quod Domino nostro Imperatori respondeatis gratiose, ita quod aperiatur via, sicut \& ipse petit, expedita \& apta nunciis scepe mittendis a vobis ad ipsum, \& ab ipso ad vos, \& ad conferendam inter vos \& ipsum amicitiam : quia si hoc feceritis magnum bonum subsequetur pro salute animarum, \& pro exaltatione fidei Christiance, quia favor ejus in imperio suo facere potest innumera bona, \& indignatio ejus innumera mala, \& ideo recommendetis nos sibi, filios vestros, \& fratres, \& fideles alios, qui sunt in imperio ejus, quia si ita feceritis, bono maxima facietis, cum ita factum fuerit, quod ex parte vestra diversis temporibus tres vel quatuor nunc iverunt ad prafatum Imperatorem Dominum nostrum, a quo gratiose recepti fuerunt, \& honorati \& remunerati; \& ex tunc dictus Imperator nullum a vobis, vel a Sede Apostolica responsum accepit, licet singuli promiserunt se a vobis responsa ad profatum Dominum reportare. Quare provideat Sanctitas vestra, quod hac vice, \& deinceps habeat certum a vobis responsum \& nuncium, sicut decet Sanctitatem vestram, quia magna verecundia est Christianis in partibus istis, quando mendacia inveniuntur in ipsis. Scripta in Cambalec in anno Rati, mense sexto, tertia die lunationis" [23, p. 209-210].

other rarities from the sun-setting. Written in Cambalec, in the year of the Rat, in the sixth month, on the third day of the Moon" - Transl. by Henry Yule in [26, p. 181]. - The "Seven Seas" is a figurative term that can be traced back to ancient times referring to all the seas and oceans of the world. The Seven Seas was part of the vernacular of several nations long before some of the oceans named were known to the inhabitants of Europe and Asia. The Seven Seas are referred to in the literature of the ancient Hindus, Chinese, Persians, Romans and other nations. In each case, the term simply referred to different bodies of water. Sometimes it even referred to mythical seas. To the Persians, the Seven Seas were the streams forming the Oxus River; the Hindus used the term for the bodies of water in the Punjab. There is a group of saltwater lagoons near Venice, Italy, that the Romans called septem maria.

6 "In the strength of the Omnipotent God, and in the honour of our Lord the Emperor! We, Futim Juens, Caticen Tungii, Gemboga Evenzi, Joannes Juckoy, with our heads in the dust salute our Holy Father the Pope. ... For a long time we received instruction in the Catholic faith, with 
By the coming of the Mongolian legation in Avignon in 1338, we are informed, among others, that the successor of John of Montecorvino, Nicolò di Calabria (Nicholas de Botras, Nicolaus de Regio Calabrie, $\uparrow 1338$ ), appointed in September 1333 by Pope John XXII, had never reached his destination, as well as the other succeeding archbishops to Khanbalik $[22$, n. 113, 120] .

As regards the embassy of 1338 from the Great Khan, we find that it was graciously received by the Pope Benedict XII, one mark of his favour being to create one of the Tartar envoys sergeant-at-arms to himself [2, p. 242] $]^{8}$; that in due time the Pope delivered answers to the letters from Cathay, and that shortly afterwards he appointed legates to proceed on his own part to the court of Khanbalik, with a charge which combined the reciprocation of the Khan's courtesies with the promotion of missionary objects [26, p. 188].

Some months later the Pope named the legates, and addressed a letter to them under date II Kal. Novemb., in the fourth year of his Popedom, i.e., $31^{\text {st }}$ October, 1338. Nicolas (Nicholas, Nicolaus) Bonet (b. around 1280, d. 1343), Nicolas Nolan (Niccolo Nolano), and Gregory of Hungary were sent to Khanbalik together with John of Marignola [26, p. 188] $]^{9}$. They reached Khanbalik (Dadu) in 1342, which year is attested by Luke Wadding (1588-1657), an Irish Franciscan friar and historian, in Vol. VII of his Annales Minorum" ${ }^{10}$. He also observes: "Magnus erat sub hoc tempore in Tartaria Christianorum numerus, \& frequentes Fratrum missiones, quorum \& domicilia multa, \& opinio magna. Habebant domum prope magni Chami palatium..." [23, p. 258 $]^{11}$.

wholesome guidance and abundant consolation, from your Legate Friar John, a man of weighty, capable, and holy character. But since his death, eight years ago, we have been without a director, and without spiritual consolation. We heard, indeed, that thou hadst sent another legate, but he hath never yet appeared. Wherefore we beseech your Holiness to send us a legate, wise, capable, and virtuous, to care for our souls. And let him come quickly, for we are here a flock without a head, without instruction, without consolation.... And it has happened on three or four different occasions that envoys have come on thy part to the aforesaid Emperor our Master, and have been most graciously received by him, and have had honours and presents bestowed upon them; and although all of them in turn promised to bring back thine answer to our Lord aforesaid, never yet hath he had any reply from thee or from the Apostolic See. Wherefore let your Holiness see to it that this time and henceforward there may be no doubt about a reply being sent, and an envoy also, as is fitting from your Holiness. For it is cause of great shame to Christians in these parts, when their fellows are found to tell lies. Written in Cambalec, in the year of the Rat, in the sixth month, on the third day of the Moon" - Transl. by Henry Yule in [26, p. 181-183].

7 "Fr. Nicolaus de Regio Calabrie electus est in archiepiscopum Cambaliensem" [Libri Chronicarum Fratris Elemosince (Bibl. Apostolica Vaticana, Chigiano I.VII.262, f. 103v)]. Cf. [20, n. 1037, p. 555].

8 “Anno eodem quarto [1338] ejusdem pontificatus Grandis Dominus Tartarorum misit ambassiatores, litteras, \& essenia ad dictum Dominum Papam Benedictum; quos dictus Papa habitis multis tractatibus cum Cardinalibus honorifice pertractavit, \& unum scutiferum Tartarorum ipsorum ambassiatorum servientem armorum suorum creavit...".

9 "Dilectis filiis Nicolao Boneti sacrae Theologice Professori, Nicolao de Molano, Joanni de Florentia, \& Gregorio de Hungaria Ordinis Fratrum Minorum" [23, p. 214].

10 "Legati missi a Benedico ad magnum Chamum Imperatorem, qui a Principibus Orientis honorifice habiti, pervenerunt hoc anno ad civitatem Cambaliensem" [23, p. 258].

${ }^{11}$ "At the time there was a large number of Christians in Tartary, and frequent missions of fraters with many habitations and great opinions. They had a house near to the palace of the Great Khan..." - Transl. by VL. 
Marignola's mission was important - for Mongolian-Chinese written sources not only with its spiritual message, but rather with an excellent choice of gift for the Great Khan. Western messengers brought with them, among the gifts from the Pope in Rome, a singularly auspicious present: a magnificent black horse with white hind hooves. Horses (known as Horses of Heaven, 天馬 tiānmă) from subjugate peoples were - since the times of Emperor $\mathrm{Wu}$ of Han (漢武帝 Hàn Wǔdì, $156 \mathrm{BC}-87 \mathrm{BC}$ ) - a particular sign of divine favour:

"Qua pertransita pervenimus in Cambalec, ubi est summa sedes imperii orientis, de cuius magnitudine incredibili et populo, ordine militum sileatur. Maximus autem Kaam visis dextrariis et donis pape et literis bullatis et regis eciam Roberti cum auro et nobis gavisus est gaudio magno, valde reputans bonum ymo optimum omne et summe nos honoravit" [7, p. 495 $]^{12}$.

As Sir Henry Yule (1820-1889) notes, it is pleasing to find that though our legate has no place in the Chinese Annals, the "great horses" (dextrarii), which he took with him, have. Under the year of 1342 it is recorded that there were presented to the emperor horses of the kingdom of Fulang (拂郎國 Fúláng Guó = Farang, i. e. Europe), of a race till then unknown in China. This present was highly esteemed. The event was recorded both in official Annals of the Yuan Dynasty (元史 Yuánshì), and in Outlines and details of the Comprehensive Mirror (通鑒綱目 Tōngjiàn gāngmù):

是月, 拂郎國貢異馬, 長一丈一尺三寸, 高六尺四寸, 身純黑, 後二蹄 皆白。(《元史・本紀第四十・順帝三》) $)^{13}$

"Cette année, on offrit à l'empereur des chevaux du royaume des Foulang (des Francs), d'une race jusque-là inconnue à la Chine. Ils avoient onze grands pieds six pouces de long sur six pieds huit pouces de hauteur; leur poil étoit noir par-tout le corps, excepté aux deux pieds de derrière où il étoit blanc" [6, p. 579].

"On rapporte que cette année on offrit à l'Empereur un cheval du Royaume de Foulang, long de 11 pieds 6 pouces, haut de 6 pieds 8 pouces, le corps noir avec des taches de différentes couleurs, la corne des deux pieds de dèrrière étoit blanche. Le présent fut estimé" [9, p. 279].

Gaubil tells us in another work, "Dans le palais de l'empereur, on conserve avec soin une peinture où Chun-ti, dernier empereur de la dynastie Yuen, est représenté sur un beau cheval dont on détaille toutes les dimensions. On marque

12 "After having passed it we came to Cambalec, the chief seat of the Empire of the East. Of its incredible magnitude, population, and military array, we will say nothing. But the Grand Kaam, when he beheld the great horses, and the Pope's presents, with his letter, and King Robert's too, with their golden seals, and when he saw us also, rejoiced greatly, being delighted, yea exceedingly delighted with everything, and treated us with the greatest honour". - Transl. by Henry Yule in [30, p. 213-214]. - Cf. also Národní knihovna České republiky [National Library of the Czech Republic], sign. I.D.10 (Chronica de rebus bohemicis gestis, $15^{\text {th }}$ century), f. $4 \mathrm{r}$ (facsimile online: <http://v2.manuscriptorium.com/apps/main/index.php?request=show tei_digidoc\&docId $=$ set04042630\&client $=>$ ).

13 “In that month (i.e. in autumn, $7^{\text {th }}$ lunar month of the $2^{\text {nd }}$ year of 至正 Zhizhèng era [= August 1342]) the kingdom of Fulang has tributed an exclusive horse. He was eleven feet six inches in length and six feet eight inches high, and was black all over, except the hind feet, which were white". - Transl. by VL. 
que le cheval fut offert à Chun-ti par un étranger du royaume de France. C'étais sans doute ou un marchand ou un curieux voyageur" [10, p. 187 $]^{14}$.

This extraordinary gift to the emperor and his artistic representation were recorded by the scholar Ouyang Xuan (歐陽玄 Ōuyáng Xuán, 1283-1357) in his Ode on the Heavenly Horse (天馬頌 Tiānmă song or 天馬賦 Tiānmă fü) ${ }^{15}$.

But return back to the Christians at the Mongolian-Chinese court. Marignola, in his Cronica Boemorum, identifies the Christian dignitaries at the court of the Great Khan as the Alans. We know of them from earlier sources, but mostly under the generic name "Christians" or "Nestorian Christians" .

Who were these Alans? The Alans (or Alani) were an Iranian nomadic pastoral people of antiquity. The first mentions of names that historians link with the Alani appear at almost the same time in Greco-Roman geography and in the Chinese dynastic chronicles. From Chinese early sources (The Later Han Dynasty annals, 後漢書 Hòu Hàn shū), covering the period of 25-220 AD, we know them under name of 阿蘭聊 Álánliáo [13]. Their migrations, first to Central Asia in the first century $\mathrm{AD}$ and then, during the fourth and fifth centuries $\mathrm{AD}$, to the West Europe and North Africa, are best known.

As the Alans, whose original area of settlement was north of the Caucasus, converted to Byzantine Orthodoxy in the first quarter of the tenth century, they were collectively mentioned as Byzantine-rite Christians in the thirteenth century. In the Northern Caucasus, roughly in the location of latter-day Circassia and modern North Ossetia-Alania, existed from the eighth or ninth century until its destruction by the Mongol invasion in 1238-1239, a medieval kingdom of Alania. Most Alans submitted to the Mongol Empire in 1239-1277. They participated in Mongol invasions of Europe and the Song Dynasty in Southern China.

In 1253, the Flemish Franciscan missionary and explorer William of Rubruck (Ruysbroeck, Rubroek, Ruysbroek, Roebroeck, Rubroeck, Roebroek, Rubruck, Ruysbrock, Ruysbrok, Rubruquius etc., c. 1220 - c. 1293) reported numerous Europeans in Central Asia $[14 ; 15]$. It is also known that 30,000 Alans formed the royal guard $(a s u d)^{17}$ of the Yuan court in Dadu or Khanbalik (Beijing) [26, p. 184]. Marco Polo later reported their role in the Yuan Dynasty in his book Il Milione (see below).

John of Montecorvino (Giovanni da Montecorvino, 1247-1328), archbishop of Dadu (Khanbalik), reportedly converted many Alans (he did not mention their

${ }^{14}$ A Ming copy of Yuan original painting of this horse by Zhou Lang (周郎: 天馬圖, 1342) has been recently rediscovered in Beijing and is exhibited in the National Palace Museum [1, p. 103-105].

${ }^{15}$ An English translation by Lauren Arnold see [1, p. 103-104]. She erroneously states that it was published in the Annals of the Yuan Dynasty (元史 Yuánshi), however (as seen in the photo) the text was taken from The Collected Works of Guizhai, j. 1 (《圭齋文集》卷一). (http://ctext.org/library.pl?if=gb\&file=50372\&page=34) Guizhai was the pen name (號 hào) of Ouyang Xuan.

${ }^{16}$ According to the present-day Franciscan historian and missionary Vincenzo Brocanelli, a total of 242 Friars Minor, among them 3 archbishops and 11 bishops, went to China in the years 1334, 1336, 1362 and 1369 [4, p. 16].

${ }^{17}$ Asud (in Chinese sources mentioned as 阿速特 āsùtè, 阿速 $\bar{a} s u ̀$, 阿闌 ālán, 阿思 $\bar{a} s \bar{\imath}$, 阿宿 $\bar{a} s \grave{u}$, 阿蘇特 $\bar{a} s \bar{u} t e ̀$, 阿速惕 $\bar{a} s \grave{u} t i)$ was a guard and military group of Alani origin. 
name) to Roman Catholic Christianity in addition to Armenians in China. For example, in his letter of 8 January 1305, he wrote:

"Unam ecclesiam edificavi in civitate Cambaliech, ubi est precipua residentia Regis, quam ante sex annos complevi, ubi etiam feci campanile et ibi tres campanas posui. Battizavi etiam ibidem, ut existimo, usque hodie, circa sex millia personarum. Et nisi fuissent supradicte infamationes, battizassem ultra xxx milia..." [8, p. 347; 21, Appendice II, p. 124 $]^{18}$.

As regards the spread of Nestorian Christianity in China Proper at this period, already Marco Polo (Marcus Paulus Venetus, Marco Polo da Venesia, 12541324), a well-known Venetian merchant traveller to Central Asia and China, testify existence of Christians. He also speaks of them specifically in the remote province of Yunnan (see below), and in Jingjiang Prefecture (京江府 Jingjiāng fü, modern Zhenjiang, 鎮江 Zhènjiāng), where they had two churches, built in the traveller's

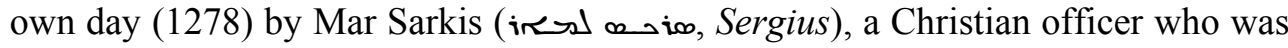
governor there.

According to the Annals of the Yuan Dynasty, in 1229 and 1241, when army of

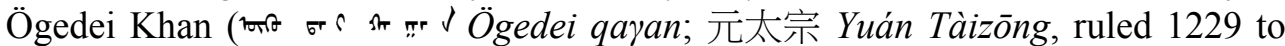
1241) reached the Country of the Aas (Alans), their chief submitted at once and a body of one thousand Alans was kept for the private guard of the Great Khan.

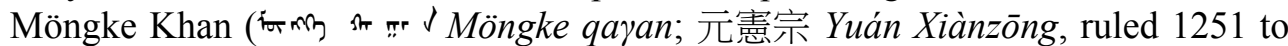
1259) enlisted in his bodyguard half of the troops of Arslan, an Alan prince, whose younger son Nicholas took a part in the expedition of the Mongols against Qarajang (Yunnan) ${ }^{19}$ [26, p. 187, n.; see also 2, p. 84-90]. This Alan imperial guard was still in existence in 1272, 1286 and 1309, and it was divided into two corps with headquarters in the Lingbei Province (嶺北等處行中書省 Lingběi dèngchù xíngzhōngshūshěng, Karakorum, st mentions Alania among the countries conquered by the Mongols, and devotes a whole chapter to an account of the slaughter of certain Alans who were Christians

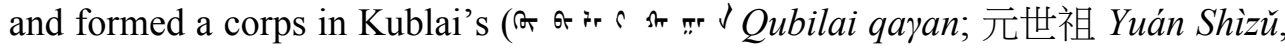
ruled 1260 to 1294) army [2, p. 86]. The Franco-Venetian version has this text:

"CCXX Ci devise des seingnorç des Tartars dou Ponent.

Le primer seignors des Tartars dou Ponent fu Saïn, qe mout fu grant roi e poisant. Ceste roi Saïn conquisté Rosie et Comanie et Alanie et Lac et Mengiar et Çic et Gucia et Gaçaric. Toutes cestes provences conquisté le roi Saïn" [17] ${ }^{20}$.

18 "I have built a church in the city of Cambaliech, in which the king has his chief residence. This I completed six years ago; and I have built a bell-tower to it, and put three bells in it. I have baptised there, as well as I can estimate, up to this time some 6000 persons; and if those charges against me of which I have spoken had not been made, I should have baptized more than 30,000. And I am often still engaged in baptizing" - Transl. by Henry Yule in [27, p. 46].

${ }^{19}$ During the Yuan period, the territory of Yunnan was named Qarajang (officially Qarajang

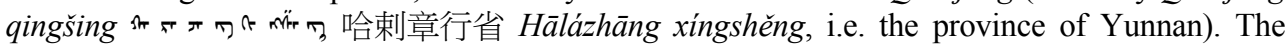
origin of this name might lie in the Mongolian name of the Black Man (烏蠻 Wūmán), or Cuan (藇 Cuàn $)($ qara $=$ black, jang $=$ Cuan?), the ancestors of modern Yi (彝族 Yizú). Marco Polo mentions this name (in the form of Caragian or Carayam, Caraiam, Caraian, Carazan) in two chapters of his book: in Chapter CXIX it is used as the name for the whole province of Yunnan, and in Chapter CXX it indicates Dali, both the region and its seat [16, p. 20-21; 12, p. 100].

20 "221. Here the lords of the Tartars of the West are described. 
The number and influence of Christians in China at the end of the thirteenth century may be gathered from the letter of John of Montecorvino [27, p. 46 seqq.], and in the first part of the following century from the report of the Archbishop of Soltania, who describes them as more than thirty thousand in number, and passing rich people [28, p. 102]. Probably there was a considerable increase in their numbers about this time, because Odoric of Pordenone (also known as Odoric of Udine, Odoric of Friuli etc.; ca. 1280/1286-1331), in about 1324, found (three) Nestorian churches in the city of Yangzhou (揚州 Yángzhōu) ${ }^{21}$, where Marco would probably have mentioned them had they existed in his time. That Christians continued to rise in influence during the short remainder of the Mongol reign appears probable from the position which we find the Christian Alans to occupy in the empire at the time of the visit of John of Marignola [29, p. 119].

Odoric several times mentioned "great barons" (magni barones aspicientes solum ad personam regis) at the court of the Great Khan, for example:

"Ego frater Odoricus ibi fui bene tribus annis in hac sua civitate et multotiens in istis suis festis presens fui, nam nos fratres minores in hac curia sua habemus locum deputatum, et nos semper sic oportet ire et dare sibi benedictionem nostram, unde diligenter petii et inquisivi a Christianis, Sarracenis cunctisque ydolatris a nostris etiam conversis ad fidem, qui in ilia curia magni sunt barones aspicientes solum ad personam regis..." [32, p. 321 $]^{22}$.

Interesting is Odoric's pleasant anecdote concerning his presentation of apples to Yesün Temür Khan ( $\pi$ r r r r fo \& st $\pi$ r \ Yesüntemür qayan; 元泰定帝 Yuán Tàidingdì, ruled 1323 to 1328 ) which reveals the easy acceptance of the Latin Christians by the emperor and his top generals - the hereditary Alan guards that protected Kublai's descendants. The event happened apparently during Khan's journey from the Summer Palace in Shangdu to Khanbalik. Shangdu (上都

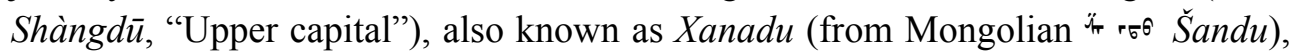
was the capital of Kublai Khan's Yuan dynasty in China, before he decided to move his throne to Khanbalik. According to the text know as De reverentia magni Chanis (On the respect of the Great Khan), Odoric and (four) ${ }^{23}$ other Franciscans,

The first lord of the Tartars of the West was Sain, who was a great and powerful king. This King Sain conquered Russia, Cumania, Alania, Lac, Mengiar, Çic, Gutia, and Khazaria [Gaçaria]. All these provinces were conquered by King Sain [18, p. 213]. - The "Tartars of the West" are the khans of the Golden Horde; the "Tartars of the East" are the Ilkhans of Persia.

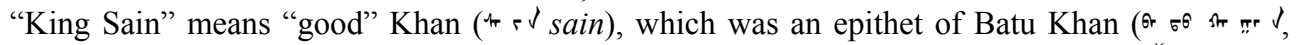

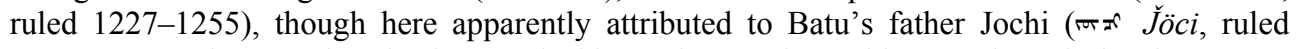
1225-1227). The French redactions omit this section on the Golden Horde entirely; the Tuscan redaction retains a much abbreviated version $[5$, p. 81].

21 "...ubi est locus fratrum minorum. In hac civitate eciam sunt ecclesie Nestorianorum". PRAHA, Knihovna Národního muzea [The National Museum Library], XVII.E.2., f. 8rb. - Only in some manuscripts it is stated that there were three Nestorian churches [29, p. 119].

22 "I, Friar Odoric, was full three years in that city of his, and often present at those festivals of theirs; for we Minor Friars have a place assigned to us at the emperor's court, and we be always in duty bound to go and give him our benison. So I took the opportunity to make diligent inquiry from Christians, Saracens, and all kinds of idolaters, and likewise from our own converts to the faith, of whom there be some who are great barons at that court, and have to do with the king's person only..." [31, p. 225]. - These great courtiers may have been some of the Christian Alans of whom we hear some years later in connection with the legation of Marignola.

${ }^{23}$ This number is mentioned only in some mss. 
one of whom was a bishop, met the Great Khan on his way from Shangdu and saluted him by singing the hymn VENI CREATOR SPIRITUS ${ }^{24}$. In this episode we know again on "four barons who go beside him" (quatuor barones qui erant iuxta eum), i.e. Christian Alan guards in the service of the Great Khan.

What happened to the multitude of converts that John of Montecorvino and others claimed for Rome, when the Ming dynasty took control in 1368? As Lauren Arnold writes in her Princely Gifts and Papal Treasures, no huge cataclysm took place in terms of Chinese Christianity during the change from the Yuan to the Ming dynasty, but the Christian communities founded by the Franciscans probably became very discreet in the outward manifestations of their faith. This was a period of intense anti-foreign feeling, when non-Chinese graveyards were despoiled and their stones incorporated into city walls, as they were in Yangzhou (揚州 Yángzhōu) and Quanzhou (泉州 Quánzhōu) [1, p. 143-144].

A recent study suggests that Christian worship, instead of dying out under this pressure, simply became more circumspect in its visible forms of worship. Bernward $\mathrm{H}$. Willeke uncovered evidence that some fifteenth-century Christians migrated from the coast or other cities to smaller communities, in order to worship quietly as they wished [24, p. 64-70]. Latin Christianity in the beginning of the Ming dynasty might have hidden discreetly in the coastal cities and elsewhere, well into the early sixteenth century. It was slowly contracting from attrition, and suffering from lack of renewal. Very likely Latin Christians persisted in ever-smaller groups, as Nestorian enclaves did, until an official persecution caused by Muslim unrest (ca. 1543) violently ended all foreign-based religions in China [1, p. 145].

\section{REFERENCES}

1. Arnold L. Princely Gifts and Papal Treasures: The Franciscan Mission to China and Its Influence on the Art of the West, 1250-1350. San Francisco, Desiderata Press, 1999. $239 \mathrm{p}$.

2. Baluzius St. (Étienne Baluze). Vitce paparum avenionensium: Hoc est Historia Pontificum Romanorum qui in Gallia sederunt ab anno Christi MCCCV usque ad annum $M C C C X C I V$. Stephanus Baluzius Tutelensis magnam partem nunc primum edidit, reliquam emendavit ad vetera exemplaria, Notas adjecit et collectionem actorum veterum Tome 1. Parisiis, Apud Franciscum Muguet Regis, Cleri Gallicani, \& Illustrissimi Archiepiscopi Parisiensis Typographum, 1693. Cum Privilegio Regis. (In Latin)

3. Bretschneider E. Mediceval Researches from Eastern Asiatic Sources: fragments towards the knowledge of the geography and history of Central and Western Asia from the $13^{\text {th }}$ to the $17^{\text {th }}$ century. Vol II. With a reproduction of a Chinese mediæval map of Central and Western Asia. London, Trübner \& Co., Ludgate Hill, 1888. 371 p.

4. Brocanelli Br. V., OFM. Franciscans without frontiers. [Strasbourg], Éditions du Signe, 2008. viii $+95 \mathrm{p}$.

5. Dashdondog B. Submission to the Mongol Empire by the Armenians. Mongolian and Tibetan Quarterly, 2009, 18 (3), pp. 76-103.

${ }^{24}$ VENI CREATOR SPIRITUS ("Come Creator Spirit”) is a hymn believed to have been written by Rabanus Maurus, a Frankish Benedictine monk, the archbishop of Mainz in Germany and a theologian, in the $9^{\text {th }}$ century. When the original Latin text is used, it is normally sung in Gregorian chant. This hymn is sung in a variety of liturgical occasions. 
6. De Mailla P. J.-A.-M. Histoire générale de la Chine, ou Annales de cet empire; traduites du Tong-kien-kang-mou, par le feu Père Joseph-Anne-Marie de Moyriac de Mailla, Jésuite François, missionnaire à Pékin, publiées par M. l'Abbé Grosier, et dirigées par M. Le Roux des Hautesrayes, Conseiller-Lecteur du Roi, Professeur d'Arabe au Collège Royal de France, Interprète de Sa Majesté pour les Langues Orientales. Ouvrage enrichi de figures \& de nouvelles cartes géographiques de la Chine ancienne \& moderne, levées par ordre du feu Empereur Kang-Hi, \& gravées pour la première fois. Tome neuvième. A Paris, chez Ph.-D. Pierres, Imprimeur du Grand-Conseil du Roi, \& du Collège Royal de France, rue Saint-Jacques, \& Clousier, Imprimeur-Libraire, rue Saint-Jacques, 1779. Avec approbation, et privilége du Roi. (In French)

7. Emler J. (ed.). Kronika Jana z Marignoly. Johannis de Marignola Chronicon. Fontes rerum Bohemicarum. Tom. III. Prameny dějin českých, vydávané z Nadání Palackého péčí „Spolku historického v Praze“. V Praze 1882. Nákladem Nadání Františka Palackého. V komissí kněhkupectví Dr. Grégr a Ferd. Dattel, pp. 485-604. (In Latin)

8. Epistolæ Fr. Iohannis de Monte Corvino. Sinica Franciscana. Vol. I. Itinera et relationes fratrum minorum sceculi XIII et XIV. Collegit, ad fidem codicum redegit et adnotavit P. Anastasius van den Wyngaert O. F. M. Ad claras aquas (Quaracchi - Firenze), Apud Collegium S. Bonaventuræ, 1929, pp. 340-355. (In Latin)

9. Gaubil P. [Antoine]. Histoire de Gentchiscan et de toute la dinastie des Mongous, ses successeurs, conquérans de la Chine; tirée de l'Histoire chinoise, et traduite par le R.P. Gaubil de la Compagnie de Jesus, Missionaire à Péking. A Paris, Chez Briasson, Libraire, rue Saint Jacques et Piget, Libraire, sur le Quay des Augustins, 1739. Avec approbation et privilege du Roy. (In French)

10. Gaubil P. [Antoine]. Traité de la chronologie chinoise, divisé en trois parties; composé par le Père Gaubil, missionnaire à la Chine, et publié, pour servir de suite aux Mémoires concernant les Chinois, par M. Silvestre de Sacy. A Paris. Chez Treuttel et Würtz Libraires, ancien hôtel de Lauraguais, rue de Lille, no. 17; et à Strasbourg, même maison de Commerce, 1814. (In French)

11. Golubovich G. Biblioteca bio-bibliografica della Terra Santa e dell'Oriente francescano. Tomo IV: Annali di Terra Santa dal 1333 al 1345. Ad claras aquas (Quaracchi - Firenze), Apud Collegium S. Bonaventuræ 1923. v + 503 p. (In Italian, Latin)

12. Haw S.G. Marco Polo's China: A Venetian in the Realm of Khubilai Khan. London, Routledge, 2006. vii +214 p.

13. Hill J.E. Annotated Translation of the Chapter on the Western Regions according to the Hou Hanshu. The Xiyu juan "Chapter on the Western Regions" from Hou Hanshu 88. $2^{\text {nd }}$ Draft Edition, 2003 (online edition: <http://depts.washington.edu/silkroad /texts/hhshu/hou_han_shu.html>)

14. Jackson P. The Mongols and the West, 1221-1410. London, Longman, 2005. xxxiv $+414 \mathrm{p}$.

15. Jackson P. (ed. \& trans.), Morgan D. (ed.). The Mission of Friar William of Rubruck: His Journey to the Court of the Great Khan Möngke, 1253-1255. London, Hakluyt Society 1990. xv $+312 \mathrm{p}$.

16. Liščák V. Marco Polo and Yunnan. The Thai-Yunnan Project Newsletter (Canberra), 1992, 17, pp. 20-25.

17. Marco Polo. Il Milione. Le devisement dou monde, texte franco-venetien (proche de l'original). Il manoscritto della Bibliothèque nationale de France Fr. 1116, I. Testo, a cura di Mario Eusebi, Roma-Padova, Antenore, 2010 («Biblioteca veneta. Poliana. Documenti per l'edizione integrale di Marco Polo», 1). Edizione digitale a cura di Mario Eusebi. Marcatura digitale a cura di Luigi Tessarolo. Available at: < http://www.rialfri.eu /rialfriPHP/public/testo/testo/codice/milione.html $>$ (In Franco-Italian)

18. Marco Polo. The Description of the World. Translated, with an Introduction and Annotations, by Sharon Kinoshita. Indianapolis/Cambridge, Hackett Publishing, Inc. 2016. xxxi +238 p. 
19. Rockhill W.W. (ed. \& trans.). The journey of William of Rubruck to the eastern parts of the world, 1253-1255. London, Hayklut Society, 1900. 376 p.

20. Sbaralea J.H. [Sbaraglia G.G.], Eubel K. Bullarium Franciscanum, sive, Romanorum pontificum: constitutiones, epistolae, diplomata tribus ordinibus Minorum, Clarissarum, Poenitentium a seraphico patriarcha Sancto Francisco institutis ab eorum originibus ad nostra usque tempora concessa, Tomus V, Benedicti XI, Clementis V, Ioannis XXII Monumenta... Romae, Typis Vaticanis, 1898. xlii + 643 p. (In Latin)

21. Sella P. Il vangelo in Oriente: Giovanni da Montecorvino, frate minore e primo Vescovo in terra di Cina (1307-1328). Assisi, Edizioni Porziuncola, 2008. 150 p. (In Italian)

22. Sella P. Aspetti storici della missione di Giovanni da Montecorvino nel Cathay. Antonianum 77 (2002), pp. 475-502. Available at: <http://laveja.blogspot.tw/2011/02 /aspetti-storici-della-missione-di.html $>$ (In Italian)

23. Waddingus L., O.F.M. Annales Minorum seu Trium Ordinum a S. Francisco Institutorum auctore A. R. P. Luca Waddingo Hiberno S. T. Lectore Jubilato, \& Ordinis Chronologo. Tomus Septimus. Editio secunda, locupletior, \& accuratior opera, et studio R.mi P. Josephi Mariæ Fonseca ab Ebora S. T. Lect. Jubilati, S. \& U. Inquisitionis Consultoris, S. C. Consistor. Votantis, Episcop. Examinatoris, \& Ord. Min. in Cismont. Familia Commiss. Generalis. Romæ: Typis Rochi Bernabò, 1733. Superiorum permissu. Cum privilegio Summi Pontificis. 632 p. (In Italian)

24. Willeke B.H. Did Catholicism in the Yuan Dynasty Survive until the Present? Tripod 47, 1988, pp. 64-70.

25. Yule H., Cordier H. (eds. \& trans.). Cathay and the Way Thither being a Collection of Medieval Notices of China. Translated and edited by Colonel Sir Henry Yule, R. E., C. B., K. C. S. I. Corr. Inst. France. With a preliminary essay on the intercourse between China and the Western nations previous to the discovery of the Cape route. New edition, revised throughout in the light of recent discoveries by Henri Cordier, D. Litt., Hon. M. R. A. S., Hon. Cor. M. R. G. S., Hon. F. R. S. L., member of the Institute de France, professor at the École des Langues orientales vivantes, Paris. Vol. I-IV. London, Printed for the Hakluyt Society.

26. Yule H., Cordier H. (eds. \& trans.). John de' Marignolli and his recollections of eastern travel. Biographical and introductory notices. Cathay and the Way Thither: Being a Collection of Medieval Notices of China. Vol. III. London, Printed for the Hakluyt Society, 1914, pp. 177-208.

27. Yule H., Cordier H. (eds. \& trans.). Letters and reports of missionary friars. No. I. First letter of John of Montecorvino. Cathay and the Way Thither: Being a Collection of Medieval Notices of China. Vol. III. London, Printed for the Hakluyt Society, 1914, pp. 45-51.

28. Yule H., Cordier H. (eds. \& trans.). Letters and reports of missionary friars. No. VIII. The book of the estate of the Great Caan, set forth by the Archbishop of Soltania, circa 1330. Cathay and the Way Thither: Being a Collection of Medieval Notices of China. Vol. III. London, Printed for the Hakluyt Society, 1914, pp. 89-103.

29. Yule, Henry; Cordier, Henri, (eds. \& trans.). "Preliminary essay." Cathay and the Way Thither: Being a Collection of Medieval Notices of China. Vol. I. London: Printed for the Hakluyt Society MDCCCCXV.

30. Yule H., Cordier H. (eds. \& trans.). Recollections of travel in the East, by John de Marignolli, Papal Legate to the court of the Great Khan and afterwards Bishop of Bisignano. Cathay and the Way Thither: Being a Collection of Medieval Notices of China. Vol. III. London, Printed for the Hakluyt Society, 1914, pp. 209-269.

31. Yule H., Cordier H. (eds. \& trans.). The Eastern Parts of the World Described, by Friar Odoric the Bohemian, of Friuli, in the Province of Saint Anthony. Cathay and the Way Thither: Being a Collection of Medieval Notices of China. Vol. II. London, Printed for the Hakluyt Society, 1913, pp. 97-277. 
32. Yule H., Cordier H. (eds. \& trans.). Latin text of Odoric, from a MS. in the Bibliothèque Impériale. Descriptio Orientalium Descriptio orientalium partium fratris Odorici Boemi de Foro Julii provinciæ Sancti Antonii. Cathay and the Way Thither: Being a Collection of Medieval Notices of China. Vol. II. London, Printed for the Hakluyt Society, 1913, pp. 278-336. (In Latin)

About the author: Vladimír Liščák - Ph.D. (Ethnography), Research Fellow, Oriental Institute, Czech Academy of Sciences (Pod Vodárenskou věží 4, 18208 Praha 8-Libeň, Czechia); MOFA Taiwan Fellowship Visiting Scholar, Researcher ID: E-1717-2014 (Center for Chinese Studies, National Central Library, No. 20, Zhongshan S. Rd., Taipei, Taiwan 100-01 R.O.C.). E-mail: vliscak@gmail.com

\title{
ХРИСТИАНСКИЕ АРИСТОКРАТЫ ПРИ ДВОРЕ ВЕЛИКОГО ХАНА В ОПИСАНИИ СРЕДНЕВЕКОВЫХ ЕВРОПЕЙСКИХ ИСТОЧНИКОВ
}

\author{
Владимир Личчак \\ Институт востоковедения, Чешская Академия наук \\ Прага, Чехия \\ vliscak@gmail.com
}

\begin{abstract}
Цель исследования: “И важные государи его империи, которых называют аланами и которые правят всеми восточными землями империи (а их более тридиати тысяч этих аланов), - христиане как истинные, так и только по имени, и они называют себя рабами папы и готовы жизнь отдать за франков". Этими словами Джованни Мариньолли - известный путешественник XIV века на Дальний Восток и папский легат к Великому хану Катая - засвидетельствовал в своей Богемской хронике присутствие неких христианских аристократов аланского рода на службе у монголокитайского императора. Непосредственным стимулом для миссии Мариньолли послужило то, что в 1336 году Великий хан Ухагату Тогон-Тэмур послал делегацию из шестнадцати “франков” (Franquis) - как монголы называли европейцев - к nane, господину христиан, во Францию (ad Papam, Dominum Christianorum in Franchiam). Они привезли два письма папе: одно, как заявлялось, было от самого императора, а другое - от неких принцев христианских аланов на службе у императора. В связи с прибытием монгольской делегации в Авиньон в 1338 году нам сообщается среди прочего, что преемник Джованни да Монтекорвино, первого архиепископа Ханбалыка, так и не смог достичь места назначения, как и все последующие архиепископы Ханбалыка.

Материалы исследования: миссия Мариньолли оказалась важна не столько в связи с привезенным им спиритуальным посланием, сколько с превосходным выбором подарка для Великого хана. Среди прочих подарков Авиньонского папы западные посланцы привезли особый подарок, сопутствовавший успеху их миссии: великолепного черного коня с белыми задними копытами. В своей Богемской хронике Мариньолли указывает, что христианские сановники при дворе Великого хана были аланами. Мы знаем о них из более ранних источников, но в основном под общим именем “христиан” или “несторианских христиан”. Как сообщает Джованни да
\end{abstract}


Монтекорвино, он обратил многих аланов (не называя их поименно) в католическое христианство вместе с армянами в Китае. Согласно Анналам династии Юань, в 1229 и 1241 году, когда армия хана Угедея достигла Страны Аасов (аланов), их предводитель сразу же подчинился, и корпус из тысячи аланов содержался в качестве личной гвардии Великого хана. Хан Мунке зачислил в свои телохранители половину войск аланского принца Арслана, чей младший сын Николай принял участие в монгольской экспедиции против Караджанга (Юньнаня). Марко Поло упоминает Аланию среди стран, завоеванных монголами, и посвящает целую главу описанию бойни неких аланов, бывших христианами и составлявших отдельный корпус в армии Кубилая. Число и влияние христиан в Китае может быть установлено из письма Джованни да Монтекорвино для конца XIII века, а для первой половины следующего столетия - из отчета архиепископа Султании, сообщающего, что их было более тридцати тысяч и что они были чрезвычайно богатым народом. Рост влияния христиан в оставшийся короткий период монгольского правления кажется вероятным в связи с тем положением, в котором мы находим христианских аланов в империи к моменту визита Джованни Мариньолли. Также Одорик из Порденоне несколько раз упоминает “великих баронов" (magni barones aspicientes solum ad personam regis) при дворе Великого хана. Интересным представляется шутливый анекдот Одорика по поводу преподнесения им яблок хану Есун-Тэмуру, который показывает благоприятное отношение к латинским христианам со стороны императора и его верховных генералов, возглавлявших наследственную аланскую гвардию, охранявшую потомков Кубилая.

Результаты исследования: что случилось со множеством прозелитов, обращенных Джованни да Монтекорвино, как и со всеми другими, обратившимися ранее к папе, после того как династия Мин пришла к власти в 1368 году? Недавние исследования указывают на то, что вместо того, чтобы исчезнуть под этим давлением, христианский культ стал просто более осмотрителен в своих видимых формах поклонения. Некоторые христиане XV века переселились с побережья и больших городов в небольшие поселения, чтобы без лишнего шума исполнять свои ритуалы согласно своим пожеланиям.

Ключевье слова: религия в средневековом Китае, Юаньский Китай, христианство при дворе Великого хана, францисканские миссии, христианская аланская знать, западные средневековые источники

Для цитирования: Liščák V. The Christian Nobles at the Court of Great Khan, as Described in Mediaeval European Sources // Золотоордынское обозрение. 2017. Т. 5, № 2. C. 276-289. DOI: 10.22378/2313-6197.2017-5-2.276-289

Сведения об авторе: Владимир Лишчак - Ph.D. (этнография), научный сотрудник, Институт востоковедения, Чешская Академия наук (Pod Vodárenskou věží 4, 18208 Praha 8-Libeň, Czechia); MOFA Taiwan Fellowship Visiting Scholar, Researcher ID: E-1717-2014 (Center for Chinese Studies, National Central Library, No. 20, Zhongshan S. Rd., Taipei, Taiwan 100-01 R.O.C.). E-mail: vliscak@gmail.com 